\title{
Assessing Participation and Position of Vietnam in Global Value Chains
}

\author{
Shashi Kant Chaudhary, PhD*
}

DOI: https://doi.org/10.3126/jnbs.v14i1.41486

Received on 19 May 2021

Accepted on 16 November 2021

\begin{abstract}
Vietnam's policy of openness to trade and investment has made it integrated very quickly with the global production networks, also known as global value chains, which has brought many visible fortunes to it in terms of socio-economic achievements. To have a deeper insight into the prospects and constraints of its integration into global value chains, and also to assess its degree of integration, this paper has employed Koopman et al. (2010) approach to measure the participation index, and position index. The analysis shows that the participation of Vietnam in global value chains has increased significantly in the last two decades based on strengthening FDI-led exports of Vietnam. It also shows that most of the exporting industries are located in the middle-stream in the value curve and are net buyers of intermediate products for exports, which infers the presence of predominant I2E practices in Vietnam. The paper also identifies and assesses the risk I2E practices are prone to. Scenario analysis suggests that Vietnam shall focus on upskilling of its labour force and developing indigenous industrial base. In the meantime, domestic firms shall be encouraged to collaborate with foreign firms and densify into global value chains.
\end{abstract}

Keywords: Backward participation, forward participation, global value chains, position index, Vietnam

\section{INTRODUCTION}

Global value chains ${ }^{1}$ have become a dominant feature of international trade and investment (OECD, 2015). Progress in information and communication technology reforms in trade policies, and reduction in the regulatory barriers, especially after the mid-1980s led the manufacturing firms in exploring the most efficient locations for production process which has resulted in fragmented production process across several locations in the world (Jones \& Kierzkowski, 2001). Because of this new trend in the global production network, integrations of developing

${ }^{*}$ Dr. Chaudhary is a Senior Teaching Fellow in British University Vietnam.

Email: saw_sea@outlook.com

${ }^{1}$ Global value chain is a phenomenon in which a production process is fragmented into multi-stage tasks and is completed by different companies located over different countries (UNCTAD, 2015; WDR, 2020). The production process of mobile phones, automotive, textile and footwear, etc. are some common examples of global value chains. 
countries like China, Mexico, Bangladesh, Vietnam, etc. have increased significantly in global value chains in comparison to what they used to have a couple of decades ago. Participation in global value chains has brought several fortunes to these developing countries, viz. (i) they did not need to build a whole course of production capacity; instead, they just needed to use their comparative advantages to concentrate on a specific production process (Kowalski et al., 2015); (ii) increased participation in global value chains generated new job opportunities (OECD, 2014); and (iii) also provided an opportunity for transfers and (or) spill-overs of the technology and management skills through local learnings (Taglioni \& Winkler, 2016). However, the amounts of benefits and their distributions are not automatic and can vary considerably depending upon two things- firstly, the way a country predominantly participates in global value chains, that is, whether as a supplier of the intermediate products, also known as forwarding participation, or as a buyer of the intermediate products, also known as backward participation and secondly, the positions of exporting industries in the value curve ${ }^{2}$. Empirical studies on mapping of global value chains, viz. Backer and Miroudot (2013), Kummritz (2014), Cheng et al. (2015), Herr et al.(2016), etc. infer that a country that predominantly supplies domestically produced intermediate products to assemblers will have strong forward participation and reaps higher domestic value addition in its exports, while a country that predominantly assembles the intermediate products into final goods and subsequently exports them, will have strong backward participation and reaps smaller domestic value addition in its exports. On the other side, by 'position of an industry in the value curve' means where exactly the reference industry is functioning in the production process, that is either on the left segment (upstream) or right segment (downstream) or middle segment (middle-stream) of the value curve. An industry's position in the value curve entirely depends on the specialized nature of the products or services it offers for trade. For example, mining industries offer unique input for other industries and thus position in the upstream. Likewise, R\&D, designing, branding, etc. also position in the upstream. On the other hand, specialized services such as distribution, marketing, after-sales customer services, etc. position the downstream. The assembly activities position in the middle-stream of the value curve. In terms of value creation, both upstream and downstream activities add larger value to the products and services than the middle-stream activities.

Vietnam started its journey as one of the poorest countries back in 1990s, but quickly achieved the status of a 'middle-income country' by 2010 and enjoyed a GDP per capita of USD 2,786 in 2020 (World Bank, 2021) leveraging on its integration into global value chains. Vietnam has moved away from the exports of primary products to the exports of manufactures and services with the support of FDI firms, which still contribute over 72 percent of the country's gross exports (GSO, 2020). Chaudhary and Nguyen (2019) have found that intra-industry trade, which is simultaneous imports and exports of goods in the same industry, has increased in Vietnam. This practice is also reflected in the increasing gaps between the values of gross exports and domestic value-added exports ${ }^{3}$ of Vietnam. However, limited numbers of studies ${ }^{4}$ are available in the context of Vietnam in terms of examining the underlying characteristics of domestic value-added contents in gross exports of it and its participation in global value chains. Only Thanh et al. (2015)

\footnotetext{
${ }^{2}$ Also known as 'smile curve,' the industries located in the either extreme of the U shaped value curve generate higher value, and the industries located in the middle generate lower value to the economy.

${ }^{3}$ Domestic value added export is the proportion of domestic value addition in the gross export of goods and services.

${ }^{4}$ These include Nadvi and Thoburn (2003), Bui et al. (2008), World Bank (2011), Tran et al. (2011), Ha (2012), Trang (2012), Dao and Nguyen (2013), Thanh et al. (2015), and Hoang and Pham (2016). Moreover, most of these studies have focused on a particular sector, for example, textile and garment, footwear, agriculture, etc. rather than the overall economy of Vietnam.
} 
and Tran et al. (2011, cited in Thanh et al., 2015) have attempted to analyze the overall picture of Vietnam by breaking down the gross exports into imported and domestic values. However, since both works have used domestic input-output table in their approaches, they have not been able to capture the flow of 'export to re-import values for Vietnam, hence making their estimates differ significantly from that of the OECD-TiVA estimates. In addition, their approaches have had some assumptive limitations such as product homogeneity, consumption of imported inputs within the same year, etc. Moreover, none of these papers have had insight and discussion about the integration of Vietnam into global value chains, which is an important feature of the Vietnamese economy in recent time though. Therefore, the researcher got motivated to undertake this research to explore the recent status and prospects of Vietnam into global value chains. This paper is expected to contribute to developing an insight into the prospects and constraints of Vietnam's integration into global value chains.

The rest of this paper has been organized as: Section 2 discusses the methodological framework adopted in this work followed by a description of data sources and the coverage of the study period in section 3. Section 4 presents the findings of the analysis and discussion, and section 5 presents the concluding remarks.

\section{METHODOLOGICAL FRAMEWORK}

This paper has employed three steps in assessing the participation and position of Vietnam in global value chains. Firstly, estimation of global value chains participation indices of exporting industries, and Vietnam itself; secondly, estimation of global value chains position indices of exporting industries; and thirdly, the position of the exporting industries in the value curve.

\subsection{Estimation of Global Value Chains Participation Indices}

In this framework, the work of Koopman et al. (2010) can be considered as the milestone that proposes measurement of 'global value chains participation index' for a reference industry ' $k$ ' in-country ' $i$ ' as below:

Global value chains participation index $=\frac{\mathrm{IDC}_{\mathrm{ik}}^{*}}{\mathrm{GE}}+\frac{\mathrm{FVA}_{\mathrm{ik}}}{\mathrm{GE}}$

The symbols used in the above relation can easily be generalized for Vietnam for a specific fiscal year as follow. IDC $\mathrm{ik}_{\mathrm{k}}^{*}$ is the value of domestic value-added exports of Vietnamese industry ' $\mathrm{k}$ ' in the exports of importing countries. $\mathrm{FVA}_{\mathrm{ik}}$ is the foreign value added embodied in the exports of the industry ' $\mathrm{k}$ '. GE is the gross export of Vietnam. Thus, the first term on the right hand side also measures the industry k's forward participation in global value chains, while the second term measures its backward participation in global value chains. The average value of the participation indices of all industries into consideration represents the participation index of Vietnam in global value chains.

\subsection{Estimation of Global Value Chains Position Indices}

Equation (1) does not shed light on the position of a reference industry in the value curve. Nonetheless, two approaches are available in the literature to estimate the position of an industry in the value curve- firstly, the 'global value chains position index' recommended by Koopman et al. (2010), and secondly, the 'distance to final demand index' recommended by Fally (2012). The 'global value chains position index' is a log ratio of an industry's forward participation index to its backward participation index, while the 'distance to final demand index is an index that measures how many production stages a product still requires to undergo before it reaches the final consumers. This means that a longer 'distance to final demand' suggests that industry is positioned upstream in the value curve, while a shorter 'distance to final demand' suggests that 
the industry is positioned downstream in the value curve. Nonetheless, in this paper, the researcher has adopted the 'global value chains position index' for the specified purpose because this approach also sheds light on the way a reference industry participates in global value chains. Mathematically, the 'global value chains position index' can be expressed as below:

$$
\text { Global value chainsposition index }=\mathrm{LN}\left(1+\frac{\mathrm{IDC}_{\mathrm{ik}}^{*}}{\mathrm{GE}}\right)-\mathrm{LN}\left(1+\frac{\mathrm{FVA}_{\mathrm{ik}}}{\mathrm{GE}}\right) \quad \text { (Eq. 2) }
$$

In equation (2), $\mathrm{IDC}_{\mathrm{ik}}^{*}, \mathrm{FVA}_{\mathrm{ik}}$ and $\mathrm{GE}$ has the same interpretations as stated in equation (1), and LN stands for the natural logarithmic function of the terms inside parentheses. It is important to note that equation (2) has been formulated in such a way that when a reference industry predominantly participates in global value chains by exporting intermediate products to the importing partners for their exports, the first term on the right-hand side tends to be larger and the index tends to take a positive value. On the other hand, if the reference industry predominantly participates in global value chains by purchasing intermediate products for its exports, then the second term on the right-hand side tends to be larger and the index tends to take a negative value. Therefore, if the position index takes a positive value, it means the reference industry is more likely to position in the upstream of the value curve, while if the position index takes a negative value, it is more likely to position the downstream of the value curve.

However, there is a practical limitation in this way to position industries in the value curve, and that is, it does not differentiate between the industries that position in the higherupstream (left upper end of the $U$ shaped value curve)from the ones that lie in the lower-upstream industries (in the falling apart of the $\mathrm{U}$ shape near the minimum point). The same argument is applicable in the case of industries that position in the higher-downstream (right upper end of the U-shaped value curve) and the lower-downstream industries (in the rising part of the U shape near the minimum point) in the value curve. The researcher has used the term 'middle stream for the segment in the value curve extending from the lower-upstream to the lower-downstream in the discussion onward, thus the middle-stream extends a bit in both sides of the minimum point of the value curve.

To overcome this state of confusion, the researcher has used a combination of the mean position index and the standard deviation of the position indices of all the 34 industries ${ }^{5}$ under consideration to estimate a range of 'one standard deviation on the left side (mean plus one standard deviation) to one standard deviation on the right side (mean minus one standard deviation) of the mean position index' for the base year' ${ }^{6}$. This range represents the position for the 'middle stream industries in the value curve. That means any industry with the position index falling within this range shall be considered to be positioned in the middle-stream segment. On the other hand, any industry falling on the left side of this range shall be considered to be positioned in the upstream, and that on the right side of this range shall be considered to be positioned in the downstream segment of the value curve. Nonetheless, this arrangement is based on two important underlying assumptions- firstly, that the shape of the value curve is symmetric around the mean position index; and secondly, that the position index series is normally distributed. These assumptions have been tested using the measure of skewness and the ShapiroWilk statistic in the series. The estimates of equations (1) and (2), and the above-mentioned measures have been presented in section 4 .

5 There are 36 industries in total in the data series, however, two industries do not have any exports value, hence they have been excluded from analysis.

${ }^{6} 2005$ is the starting year of the new data series of OECD stat (2018). Since the mean position index is a negative value, an addition of standard deviation ( $\mathrm{sd}>0$ ) will shift the position index towards left. 


\section{SOURCES OF DATA AND STUDY PERIOD}

A bulk of data used in the analysis have been extracted from OECD-TiVA database2018 edition $^{7}$ (spanning over 2005 to 2015), and only a couple of aggregate values from its 2016 edition (spanning over 1995 to 2011) to extend the study period from 1995 to 2015 to have a better understanding of the historical pattern in participation index. However, in the analysis of industries' level position indices, the study uses data from OECD-TiVA 2018 edition only since the industries level classification of the 2016 edition is not directly comparable with that of the 2018 edition. They have adopted different versions of ISIC (International Standard Industrial Classification of All Economic Activities).

\section{FINDINGS AND DISCUSSION}

\subsection{Participation of Vietnam in Global Value Chains}

The participation of Vietnam in global value chains has significantly increased from 34 percent in 1995 to 56 percent in 2015 riding on its backward participation. During this period, the proportions of backward participation have increased substantially to over 44 percentage points while that of the forward participation has fallen to 11 percentage points, causing a large gap between them (Table 1). This also affirms the 'imports for exports (I2E)' practices that have been taken place in Vietnam, which, in the words of Nakamura (2016), has helped it to emerge as the Asian manufacturing powerhouse. With its recent level of participation in global value chains, Vietnam stands $9^{\text {th }}$ in the world, while $3^{\text {rd }}$ in the ASEAN region, and is expected to surpass Malaysia soon (Figure 1). However, in terms of forwarding participation, its rank is $61^{\text {st }}$ in the world ${ }^{8}$ and stands at the end in the ASEAN region. Nonetheless, the imported items and services have supported Vietnam in maintaining its competitiveness in the world market. Despite having skills constraints, it is a leading exporter of computer and electronic products, and electrical equipment in the world.

\section{Table 1}

Global Value Chains Participation Indices of Vietnam by Years

\begin{tabular}{cccc}
\hline Year & $\begin{array}{c}\text { Forward participation } \\
\text { index }\end{array}$ & $\begin{array}{c}\text { Backward participation } \\
\text { index }\end{array}$ & $\begin{array}{c}\text { Total participation } \\
\text { index }\end{array}$ \\
\hline 1995 & 12.6 & 21.6 & 34.2 \\
2000 & 19.5 & 27.2 & 46.7 \\
2005 & 14.5 & 36.1 & 50.6 \\
2010 & 12.5 & 40.5 & 53.0 \\
2015 & 11.1 & 44.5 & 55.6 \\
\hline
\end{tabular}

Source: Researcher's estimate. Data source: OECD.stat (2016 \&2018)

7 This is the most recent database published by OECD on Trade in Value Added (TiVA) indicators.

${ }^{8}$ In the rank by forward participation index, Brunei, Saudi Arabia, and Kazakhstan which are rich in exporting crude oil and natural gases occupy the top three positions with shares 41.1, 36.8 , and 35.1 percentage points respectively. 


\section{Figure 1}

Global Value Chains Participation Index of the Top 47 Countries in the World in 2015.

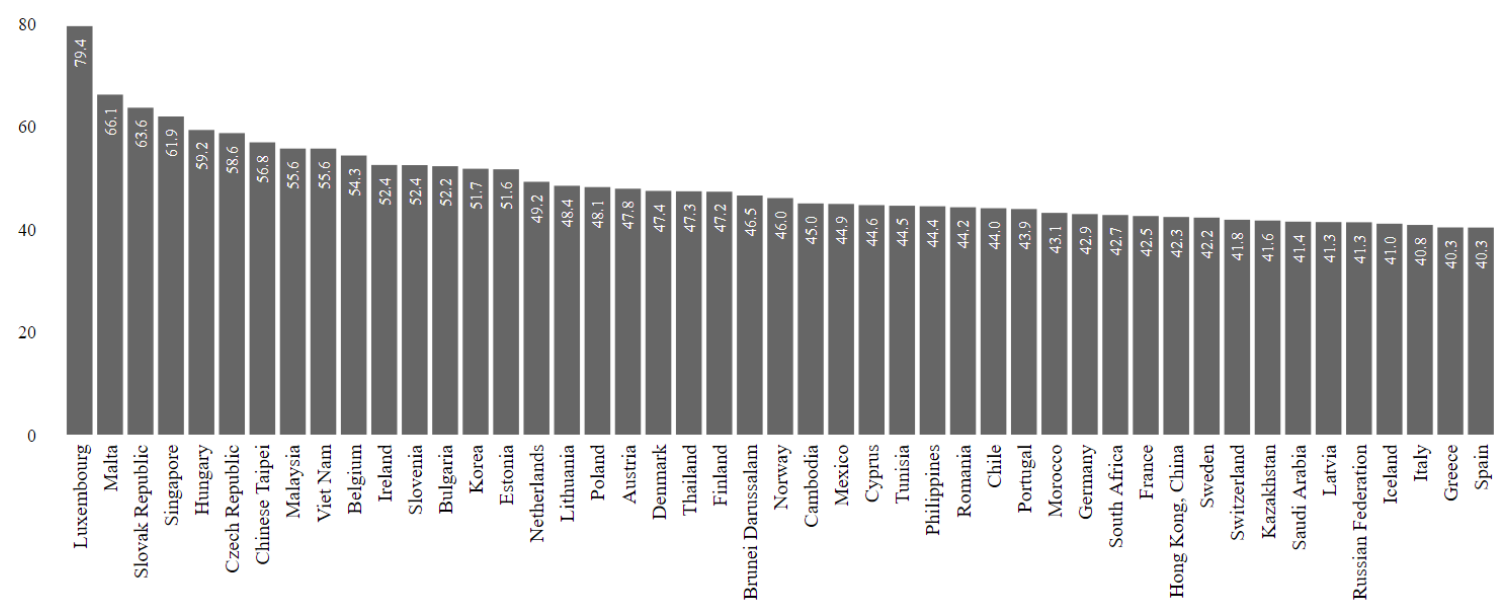

Source: Researcher's contribution. Data source: OECD.stat (2018)

A breakdown of the global value chains participation indices to the industry level shows that Vietnam has been highly active in computer and electronics, electrical equipment, machinery equipment, transport equipment, textile and footwear, and the processing industries, mainly through backward participation. Among the business-related services, the indices are higher for information and communication, and transport and storage (Appendix A). Notably, the participation of computer and electronics, and electrical equipment has grown remarkably in comparison to 2005, by 31 percent and 24 percent respectively. The global value chains participation of textile and footwear, foods and beverages, machinery equipment and transport equipment have also grown, albeit slowly. On the other hand, the global value chains participation of agriculture and mining industries has remained low since the beginning and has remained almost unchanged. Since the global value chains participation depends on the technical characteristics of industries' products, for example, the electronics, computers and their parts, machinery and equipment are easy to separate into discrete components, easy to produce separately, and also easy to transport to the low-cost locations for assembly process; the observed pattern of global value chains participation of Vietnam is not surprising. These industries normally rank higher in terms of the global value chains of the host countries like Vietnam via increasing backward participation rate.

\subsection{Position of Vietnamese Industries in Global Value Chains}

The estimated values of global value chains indices for all 34 industries into consideration for years 2005, 2010, and 2015 have been provided in Appendix B. The position indices of all 34 industries are negative, which means that they are net buyers of intermediates for their exports. This is a clear indication that assembly activities have been taking place in those industries. Nonetheless, prior to going into the discussion of the positioning of these industries in the value curve, a confirmatory test has been undertaken by employing skewness, and ShapiroWilk test, to confirm that distribution of the series of the global value chains position indices are symmetric and normal. The results are presented in Table 2. Since the absolute values of skewness are less than 0.5 , the distribution is confirmed to be symmetric. Likewise, the Shapiro- 
Wilk statistics for none of the three series are found significant at 5 percent level, which means the null hypothesis that 'data series is normally distributed' cannot be rejected. This confirms the normality assumption of the global value chains indices.

\section{Table 2}

Normality Test for the Data Series of Global Value Chains Position Indices

\begin{tabular}{lcccc}
\hline \multirow{2}{*}{ Index series } & \multirow{2}{*}{ Skewness } & \multicolumn{3}{c}{ Shapiro-Wilk } \\
\cline { 3 - 5 } & & Statistic & $\mathrm{df}$ & Sig. \\
\hline Position indices (2005) & 0.259 & 0.943 & 34 & 0.074 \\
Position indices (2010) & 0.180 & 0.945 & 34 & 0.088 \\
Position indices (2015) & 0.007 & 0.960 & 34 & 0.242 \\
\hline
\end{tabular}

\section{Source: Researcher's estimate}

Next, as proposed in the methodological framework, the range for the middle-stream industries in the base year 2005 , extends from negative 0.18 to negative 0.40 , i.e. [-0.18 to -0.40$]$. This also infers that an industry with a position index greater than negative 0.18 is positioned upstream and that smaller than negative 0.40 is positioned downstream (Appendix B). Based on these criteria, it is seen that most of the manufacturing industries including textile and footwear, and foods and beverages are positioned in the middle-stream. They together have contributed over 62 percent to the domestic value-added exports of Vietnam in 2015. Other six manufacturing industries including fabricated metal, computer and electronics, electrical, machinery and other transport equipment are located downstream, and they together have contributed 14 percent in the domestic value added exports of Vietnam in 2015. Three industries are positioned upstream, which are related to the support services, and their contribution is less than one percent in the domestic value added exports of Vietnam. In terms of total contribution by categories, the middlestream industries together contribute over 85 percent in the domestic value added exports of Vietnam and show their dominance in the export sector of Vietnam. Nonetheless, except for coke and refined petroleum products, and basic metals which are moving towards upstream, others are moving towards downstream in the value curve. Since, the major activities that take place in the downstream segment of the value curve are distributions, sales, and after-sales services, therefore, this trend indicates a gradual improvement in the connectivity of Vietnamese domestic firms in the international market.

\section{CONCLUDING REMARKS}

Vietnam's economy has grown rapidly in the past 25 years, and it has been able to maintain a stable GDP growth rate of over 5 percent, mainly relying on its strengthening exports 9 . With that its participation in global value chains has also increased significantly. The analysis has shown that most of the contributing industries are located in the middle-stream in the value curve and are net buyers of intermediate products for exports. That is why the gross exports value of Vietnam has risen significantly in comparison to its domestic value-added exports. With this I2E model of growth, Vietnam has made notable improvements in its socio-economic indicators since the start of its journey back in 1990s. However, this model, to work smoothly requires low-cost labour forces. Till now, Vietnam has had maintained its comparative advantage in a cheap labour force and has been able to attract baskets of foreign direct investment projects into the country. However, now it is time to assess how long more this strategy may work. With the rise in the

\footnotetext{
${ }^{9}$ According to Nguyen and Chaudhary (2018), both short-run and long-run relationship exists between value added exports and GDP of Vietnam. Moreover, one percent rise in domestic value added exports contributes in 0.73 percent rise in the real GDP value of Vietnam.
} 
living standards of Vietnamese people, the wage rate is certain to rise sweeping away this comparative advantage in the future, which means a wave of assembly jobs is more likely to flow out of Vietnam. In addition, this model is also prone to the consequences of automation of assembly activities in the light of Industry $4.0^{10}$ buzz across the globe. Hence, Vietnam has two options ahead - either continue with the existing model as an export platform in global value chains, specializing in assembly activities, or move up (or down) along the value curve towards upstream (or downstream)to capture higher value addition for its activities by upskilling its labor force and developing own indigenous industrial base. The failure of the Mexican growth model has shown that wage suppression is not a sustainable strategy to reap the benefits of global value chains. Instead, some lessons from Germany, Japan, Asian Tigers ${ }^{11}$ and China might be worthful in envisaging the future policies and ways ahead for Vietnam. German and Japanese export-led growth booms were based on their indigenous industrial-based exports. The Asian Tigers also followed a similar strategy, but they also added the acquisition of foreign technology in their strategies. On the other side, the Chinese model is an extension of the Mexican model with two adjustments in particular- firstly, aggressive investment in upskilling its workers, in domestic R\&D, and ICT infrastructures, and secondly a policy in place for technology adoption by domestic firms. The Chinese economy has been doing well so far in comparison with the performances of other economies as mentioned above. Currently, it is not only an important player in global value chains but also has enhanced the domestic value-added exports significantly. Therefore, Vietnam shall focus on developing its indigenous industrial base and acquiring foreign technology in prioritized industries. This will require Vietnam to encourage collaboration of domestic firms with foreign firms so that local learnings can take place and the domestic firms can also densify into global value chains. These will help Vietnamese industries to upgrade their products, processes, and functions so that Vietnam overall can switch from assembling agent to the indigenous producer.

\section{ACKNOWLEDGEMENTS}

The author would like to thank and appreciate the contributions of the Editorial Board and anonymous referees in terms of providing valuable comments which helped in enhancing the quality of this paper. The author is solely responsible for any flaws and errors.

\section{REFERENCES}

Backer, K. D., \& Miroudot, S. (2013). Mapping Global Value Chains. OECD Trade Policy Paper No. 159. Organization for Economic Co-operation and Development.

Bui, T., Pham, L. H., \& Bui, C. G. (2008). Import Multiplier in Input-Output Analysis. DepocenWorking Paper No. 2008/23. Development and Policy Research Centre.

Chaudhary, S. K., \&Nguyen, K. V. (2019). Reassessing the Export Competitiveness of Vietnam. VNU Journal of Social Sciences and Humanities, 5(5), 539-549.

Cheng, K., Rehman, S., Seneviratne, D., \& Zhang, S. (2015). Reaping the Benefits from Global

${ }^{10}$ Germany Trade and Invest defines Industry 4.0 as: 'A paradigm shift . . . made possible by technological advances which constitute a reversal of conventional production process logic. Simply put, this means that industrial production machinery no longer simply "processes" the product, but that the product communicates with the machinery to tell it exactly what to do.' (Sniderman et al., 2016: p. 4-5).

${ }^{11}$ Hong Kong, Singapore, South Korea, and Taiwan. 
Value Chains. IMF Working Paper WP/15/204. International Monetary Fund.

Dao, T. A., \& Nguyen, V. S. (2013). Vietnam Agricultural Value Chain in the FTA of Asian Region. FFTC Agricultural Policy Articles. Food and Fertilizer Technology Center for the Asian and Pacific Region.

Fally, T. (2012). On the Fragmentation of Production in the US. University of Colorado-Boulder. download.cgi (editorialexpress.com)

GSO (2020). Statistical Yearbook of Vietnam 2020. General Statistics Office.

Ha, V. H. (2012). Analysis of Value Chain of Textiles and Garment Export in Vietnam (Vietnamese). Journal of Economics and Business 28, 49-59.

Herr, H., Schweisshelm, E., \& Vu T. M. (2016). The integration of Vietnam in the global economy and its effects for Vietnamese economic development. Working Paper No. 44. Global Labour University.

Hoang, T. P. L., \& Pham, T. T. H. (2016). An Analysis of Vietnamese Footwear Manufacturers' Participation in the Global Value Chain: Where They Are and Where They Should Proceed? VNU Journal of Science: Education Research 32(5), 55-65.

Jones, R. W., \& Kierzkowski, H. (2001). A framework for fragmentation. In S. Arndt, \& H. Kierzkowski (Eds.), Fragmentation: New Production Patterns in the World Economy (pp. 17-34). Oxford University Press.

Koopman, R., Powers, W., Wang, Z., \& Wei, S. J. (2010). Give Credit Where Credit is Due: Tracing Value Added in Global Production Chains. NBER Working Paper No. 16426. National Bureau of Economic Research.

Kowalski, P., Gonzalez, J. L., Ragoussis, A., \&Ugarte, C. (2015). Participation of Developing Countries in Global value chain: Implications for Trade and Trade Related Policies. OECD Trade Policy Papers, No. 179. Organization for Economic Co-operation and Development.

Kummritz, V. (2014). Global Value Chains: Benefiting the Domestic Economy? CTEI Working Paper CTEI-2014-05. Centre for Trade and Economic Integration.

Nadvi, K., \&Thoburn, J. (2003). Vietnam in the Global Garment and Textile Value Chain: Implications for Firms and Workers. Department for International Development (DFID). nadvi_thoburn.doc (psu.edu)

Nakamura, D. (2016, May 21). Buoyed by U.S. firms, Vietnam emerges as an Asian Manufacturing Powerhouse. The Washington Post. Buoyed by U.S. firms, Vietnam emerges as an Asian manufacturing powerhouse - The Washington Post

Nguyen, K. V., \& Chaudhary, S. K. (2018). An Empirical Analysis of Export-led Growth of Vietnam: Trade in Value Added (TiVA) Approach. The Journal of Business and Management, 5(1), 1-15.

OECD (2014). Global value chain: Challenges, Opportunities and Implications for Policy. Organization for Economic Co-operation and Development.

OECD (2015). Participation of Developing Countries in Global Value Chains. Summary Paper. Organization for Economic Co-operation and Development.

OECD.stat (2016 \& 2018). OECD Statistics. Organization for Economic Co-operation and Development. OECD Statistics

Sniderman, B., Mahto, M., \&Cotteleer, M. (2016). Industry 4.0 and manufacturing ecosystems: Exploring the world of connected enterprises. Deloitte Consulting.

Taglioni, D., \& Winkler, D. (2016). Making Global Value Chain Work for Development. The 
World Bank.

Thanh, V. T., Duong, N. A., \& Trinh, B. (2015). Trade-in Value Added: The Case of Viet Nam. In L.Y. Ing, \& F. Kimura, (Eds.), Production Networks in Southeast Asia (pp. 183-201). Economic Research Institute for ASEAN and East Asia (ERIA).

Trang, A. N. (2012). Vietnamese Textile and Garment Industry in the Global Supply Chain: State Strategies and Workers' Responses. Institutions and Economies 4(3), 123-150.

UNCTAD (2015). Tracing the Value Added in Global Value Chains: Product-Level Case Studies in China. United Nations Conference on Trade and Development.

WDR (2020). World Development Report 2020, Trading for development in the age of global value chains. The World Bank.

World Bank (2011). Vietnam Food Security and Rice Value Chain. Policy Note 2. The World Bank.

World Bank (2021). World Bank Open Data. The World Bank. World Bank Open Data|Data.

\section{Appendix A}

Global Value Chains Participation Indices of Vietnam by Selected Industries

\begin{tabular}{|c|c|c|c|c|c|c|c|c|c|}
\hline \multirow[b]{2}{*}{ Industries } & \multicolumn{3}{|c|}{$\begin{array}{c}\text { Forward } \\
\text { Participation }\end{array}$} & \multicolumn{3}{|c|}{$\begin{array}{c}\text { Backward } \\
\text { Participation }\end{array}$} & \multicolumn{3}{|c|}{$\begin{array}{l}\text { Participation } \\
\text { index }\end{array}$} \\
\hline & 2005 & 2010 & 2015 & 2005 & 2010 & 2015 & 2005 & 2010 & 2015 \\
\hline Agriculture, forestry, \& fishing & 0.3 & 0.2 & 0.2 & 29.8 & 30.9 & 31.7 & 30.1 & 31.1 & 31.9 \\
\hline Mining \& quarrying & 0.7 & 0.6 & 0.3 & 28.0 & 27.6 & 30.3 & 28.7 & 28.2 & 30.6 \\
\hline Food, beverages, \& tobacco & 0.8 & 0.8 & 0.7 & 34.2 & 36.6 & 37.6 & 35.0 & 37.4 & 38.3 \\
\hline Textiles, apparel, \& leather products & 1.1 & 1.0 & 1.2 & 41.5 & 44.4 & 46.2 & 42.6 & 45.3 & 47.4 \\
\hline Wood \& paper products; printing & 0.2 & 0.2 & 0.2 & 46.2 & 46.8 & 48.9 & 46.4 & 47.0 & 49.0 \\
\hline Coke \& refined petroleum products & 2.1 & 0.9 & 0.6 & 49.3 & 36.5 & 32.4 & 51.4 & 37.4 & 33.0 \\
\hline Chemicals \&pharma. products & 1.1 & 0.9 & 0.7 & 49.1 & 50.2 & 48.1 & 50.2 & 51.1 & 48.8 \\
\hline Rubber \& plastic products & 0.3 & 0.3 & 0.3 & 50.0 & 52.8 & 53.2 & 50.3 & 53.1 & 53.5 \\
\hline Other non-metallic mineral products & 0.1 & 0.1 & 0.1 & 34.1 & 35.5 & 35.6 & 34.2 & 35.6 & 35.7 \\
\hline Basic metals & 0.7 & 0.6 & 0.4 & 50.7 & 50.9 & 46.1 & 51.4 & 51.5 & 46.5 \\
\hline Fabricated metal products & 0.2 & 0.2 & 0.2 & 54.9 & 58.3 & 58.9 & 55.2 & 58.5 & 59.1 \\
\hline Computer \& electronics products & 1.7 & 1.9 & 1.7 & 47.0 & 52.2 & 62.3 & 48.8 & 54.1 & 64.0 \\
\hline Electrical equipment & 0.5 & 0.5 & 0.5 & 47.4 & 55.0 & 59.0 & 47.9 & 55.5 & 59.5 \\
\hline Machinery \& equipment, n.e.c. & 0.6 & 0.6 & 0.6 & 56.2 & 60.0 & 63.5 & 56.8 & 60.6 & 64.1 \\
\hline Transport equipment & 1.0 & 1.1 & 1.3 & 48.2 & 52.4 & 54.6 & 49.1 & 53.5 & 56.0 \\
\hline Wholesale \& retail trade & 0.7 & 0.6 & 0.5 & 19.1 & 22.0 & 24.8 & 19.8 & 22.6 & 25.3 \\
\hline Transportation \& storage & 1.0 & 0.8 & 0.6 & 35.3 & 33.2 & 33.4 & 36.4 & 34.0 & 33.9 \\
\hline Accommodation \& food services & 0.3 & 0.3 & 0.2 & 23.7 & 25.9 & 28.3 & 23.9 & 26.2 & 28.5 \\
\hline Information \& communication & 0.1 & 0.1 & 0.1 & 29.4 & 31.1 & 35.7 & 29.5 & 31.3 & 35.8 \\
\hline Financial \& insurance activities & 0.2 & 0.2 & 0.1 & 14.5 & 15.1 & 20.4 & 14.7 & 15.2 & 20.5 \\
\hline Manufacturing (aggregate) & 10.9 & 9.4 & 8.9 & 41.8 & 45.5 & 48.2 & 52.7 & 54.9 & 57.1 \\
\hline Total business sector services (agg.) & 2.6 & 2.1 & 1.7 & 26.2 & 26.5 & 28.5 & 28.7 & 28.6 & 30.2 \\
\hline Vietnam & 14.5 & 12.5 & 11.1 & 36.1 & 40.5 & 44.5 & 50.6 & $\mathbf{5 3 . 0}$ & 55.6 \\
\hline
\end{tabular}

Source: Researcher's estimate. Data source: OECD.stat (2018) 


\section{Appendix B}

Global Value Chains Position Indices of 34 Industries in Vietnam

\begin{tabular}{|c|c|c|c|c|c|c|}
\hline \multirow{2}{*}{ Industry } & \multicolumn{3}{|c|}{ Position indices } & \multicolumn{3}{|c|}{$\begin{array}{l}\text { Positions in the value } \\
\text { curve }\end{array}$} \\
\hline & 2005 & 2010 & 2015 & 2005 & 2010 & 2015 \\
\hline Agriculture, forestry \& fishing & $(0.26)$ & $(0.27)$ & $(0.27)$ & M & M & M \\
\hline Mining \& extraction of energy producing products & $(0.24)$ & $(0.24)$ & $(0.26)$ & M & M & M \\
\hline Mining \& quarrying of non-energy producing products & $(0.24)$ & $(0.25)$ & $(0.26)$ & M & M & M \\
\hline Mining support service activities & $(0.17)$ & $(0.16)$ & $(0.17)$ & $\mathrm{U}$ & $\mathrm{U}$ & $\mathrm{U}$ \\
\hline Food products, beverages \& tobacco & $(0.29)$ & $(0.30)$ & $(0.31)$ & M & M & M \\
\hline Textiles, wearing apparel, leather $\&$ related products & $(0.34)$ & $(0.36)$ & $(0.37)$ & M & M & M \\
\hline Wood \& products of wood \& cork & $(0.38)$ & $(0.39)$ & $(0.40)$ & M & M & M \\
\hline Paper products \& printing & $(0.36)$ & $(0.37)$ & $(0.37)$ & M & M & M \\
\hline Coke $\&$ refined petroleum products & $(0.38)$ & $(0.30)$ & $(0.28)$ & M & M & M \\
\hline Chemicals \& pharmaceutical products & $0.39)$ & $(0.40)$ & $(0.39)$ & M & M & M \\
\hline Rubber \& plastic products & $(0.40)$ & $(0.42)$ & $(0.42)$ & M & M & M \\
\hline Other non-metallic mineral products & $(0.29)$ & $(0.30)$ & $(0.30)$ & M & M & M \\
\hline Basic metals & $(0.40)$ & $(0.40)$ & $(0.37)$ & M & M & M \\
\hline Fabricated metal products & $(0.44)$ & $(0.46)$ & $(0.46)$ & $\mathrm{D}$ & $\mathrm{D}$ & $\mathrm{D}$ \\
\hline Computer, electronic \& optical products & $(0.37)$ & $(0.40)$ & $(0.47)$ & M & M & $\mathrm{D}$ \\
\hline Electrical equipment & $(0.38)$ & $(0.43)$ & $(0.46)$ & M & $\mathrm{D}$ & $\mathrm{D}$ \\
\hline Machinery \& equipment, n.e.c. & $(0.44)$ & $(0.46)$ & $(0.49)$ & $\mathrm{D}$ & $\mathrm{D}$ & $\mathrm{D}$ \\
\hline Motor vehicles, trailers \& semi-trailers & $(0.38)$ & $(0.41)$ & $(0.42)$ & M & $\mathrm{D}$ & $\mathrm{D}$ \\
\hline Other transport equipment & $(0.40)$ & $(0.43)$ & $(0.45)$ & M & $\mathrm{D}$ & $\mathrm{D}$ \\
\hline Other manufacturing & $(0.37)$ & $(0.39)$ & $(0.40)$ & M & M & M \\
\hline Electricity, gas, water supply & $(0.21)$ & $(0.20)$ & $(0.21)$ & M & M & M \\
\hline Construction & $(0.33)$ & $(0.36)$ & $(0.37)$ & M & M & M \\
\hline Wholesale \& retail trade; repair of motor vehicles & $(0.17)$ & $(0.19)$ & $(0.22)$ & $\mathrm{U}$ & M & M \\
\hline Transportation \& storage & $(0.29)$ & $(0.28)$ & $(0.28)$ & M & M & M \\
\hline Accommodation \& food services & $(0.21)$ & $(0.23)$ & $(0.25)$ & M & M & M \\
\hline Publishing, audio-visual \& broadcasting activities & $(0.23)$ & $(0.24)$ & $(0.28)$ & M & M & M \\
\hline Telecommunications & $(0.26)$ & $(0.28)$ & $(0.38)$ & M & M & M \\
\hline IT \& other information services & $(0.15)$ & $(0.15)$ & $(0.23)$ & $\mathrm{U}$ & $\mathrm{U}$ & M \\
\hline Financial and insurance activities & $(0.13)$ & $(0.14)$ & $(0.19)$ & $\mathrm{U}$ & $\mathrm{U}$ & M \\
\hline Real estate activities & $(0.08)$ & $(0.10)$ & $(0.13)$ & $\mathrm{U}$ & $\mathrm{U}$ & $\mathrm{U}$ \\
\hline Other business sector services & $(0.17)$ & $(0.18)$ & $(0.22)$ & M & M & M \\
\hline Education & $(0.11)$ & $(0.10)$ & $(0.14)$ & $\mathrm{U}$ & $\mathrm{U}$ & $\mathrm{U}$ \\
\hline Human health and social work & $(0.25)$ & $(0.28)$ & $(0.30)$ & M & M & M \\
\hline Arts, entertainment, recreation \& other & $(0.18)$ & $(0.17)$ & $(0.21)$ & M & $\mathrm{U}$ & M \\
\hline Manufacturing (aggregate) & $(0.25)$ & $(0.28)$ & $(0.31)$ & M & M & M \\
\hline Total business sector services (aggregate) & $(0.21)$ & $(0.21)$ & $(0.23)$ & M & M & M \\
\hline
\end{tabular}

Note. $\mathrm{U}=\mathrm{Upstream} ; \mathrm{M}=$ Middle-stream; $\mathrm{D}=$ Downstream.

Source: Researcher's estimate. Data source: OECD.stat (2018) 